\title{
Genotoxicity of aluminium oxide, iron oxide, and copper nanoparticles in mouse bone marrow cells
}

\author{
Rakhshinda Sadiq ${ }^{1}$, Qaiser Mahmood Khan², Ameena Mobeen², and Asma Shah ${ }^{1}$ \\ ${ }^{1}$ Women University Mardan Faculty of Sciences, Department of Biotechnology, Mardan, Pakistan \\ ${ }^{2}$ National Institute for Biotechnology and Genetic Engineering (NIBGE), Environmental Biotechnology Division, \\ Environmental Toxicology \& Molecular Diagnosis Lab, Faisalabad, Pakistan
}

[Received in July 2021; Similarity Check in July 2021; Accepted in November 2021]

The aim of this study was to evaluate the genotoxic effects of $\mathrm{Al}_{2} \mathrm{O}_{3}, \mathrm{Fe}_{2} \mathrm{O}_{3}$, and $\mathrm{Cu}$ nanoparticles with chromosomal aberration (CA), micronucleus (MN), and comet assays on the bone marrow of male BALB/c mice. Three $\operatorname{doses}$ of $\mathrm{Al}_{2} \mathrm{O}_{3}$, $\mathrm{Fe}_{2} \mathrm{O}_{3}(75,150$, and $300 \mathrm{mg} / \mathrm{kg})$, or $\mathrm{Cu}(5,10$, and $15 \mathrm{mg} / \mathrm{kg})$ nanoparticles were administered to mice through intraperitoneal injection once a day for 14 days and compared with negative control (distilled water) and positive control (mitomycin $\mathrm{C}$ and methyl methanesulphonate). $\mathrm{Al}_{2} \mathrm{O}_{3}$ and $\mathrm{Fe}_{2} \mathrm{O}_{3}$ did not show genotoxic effects, but $\mathrm{Cu}$ nanoparticles induced significant $(\mathrm{P}<0.05)$ genotoxicity at the highest concentration compared to negative control. Our findings add to the health risk information of $\mathrm{Al}_{2} \mathrm{O}_{3}, \mathrm{Fe}_{2} \mathrm{O}_{3}$, and $\mathrm{Cu}$ nanoparticles regarding human exposure (occupational and/or through consumer products or medical treatment), and may provide regulatory reference for safe use of these nanoparticles. However, before they can be used safely and released into the environment further chronic in vivo studies are essential.

KEY WORDS: $\mathrm{Al}_{2} \mathrm{O}_{3}$; chromosomal aberrations; comet assay; $\mathrm{Cu} ; \mathrm{Fe}_{2} \mathrm{O}_{3}$; in vivo; micronucleus; mitotic index

Promising diagnostic and therapeutic applications of nanoparticles in medicine are owed to their different biokinetics and improved interactions with cells and sub cellular structures (1). Moreover, nanomaterials can pass biological barriers easily and exert their valuable or adverse effects (2).

However, their widespread use has also raised concern about their safety and potential risks for human health (3-5). This is particularly true for $\mathrm{Al}_{2} \mathrm{O}_{3}, \mathrm{Fe}_{2} \mathrm{O}_{3}$, and $\mathrm{Cu}$ nanoparticles, which have a wide range of industrial and medical applications and low production cost.

$\mathrm{Al}_{2} \mathrm{O}_{3}$ nanoparticles are used in biosensors, biofiltration, vaccination (as an adjuvant), drug delivery (cancer therapy), and are considered a promising anti-microbial agent and sorbent for heavy metals in waste water treatment (6-8), yet recent genotoxicity reports point to liver pathology ( 9 , 10), carcinogenicity (11), inflammation (12), and cytotoxicity related to oxidative damage and loss of mitochondrial function (13).

Similar is true for $\mathrm{Fe}_{2} \mathrm{O}_{3}$ nanoparticles, used for targeted drug delivery, contrast-enhanced magnetic resonance imaging (MRI) (14-16), and thermal ablation therapy (17). A recent study (18) reported adverse effects on locomotor behaviour and spatial memory in mice receiving them intraperitoneally, most likely owed to nanoparticle

Corresponding author: Rakhshinda Sadiq, Women University Mardan Faculty of Sciences, Department of Biotechnology, East Canal Road, Mardan, Pakistan, E-mail: rak.sadiq@gmail.com accumulation, oxidative stress, DNA damage, and apoptosis. Another study in mice (19) has shown that $\mathrm{Fe}_{2} \mathrm{O}_{3}$ nanoparticles cause pathological changes in reproductive organs and the expression of heat shock gene through oxidative stress. Others have reported genetic damage, depletion in anti-enzymatic activity, and increase in lipid peroxidation in rats (20).

As for $\mathrm{Cu}$ nanoparticles, they have widely been used in the production of lubricants, polymers, ceramic pigments, metallic coating inks, and electronic devices (21-24). In medicine they can be used as a broad spectrum antimicrobial agent $(25,26)$. However, preliminary research of $\mathrm{Cu}$ nanoparticles shows their toxic effects in vitro and in vivo, such as cirrhosis and renal dysfunction in rats (27-30).

In fact, many researchers have studied the $\mathrm{Fe}_{2} \mathrm{O}_{3}, \mathrm{Al}_{2} \mathrm{O}_{3}$ and $\mathrm{Cu}$ nanoparticle genotoxicity in vitro in microorganisms and cell lines, but much is yet to learn about their genotoxicity in vivo. The aim of our study was therefore to add to scarce knowledge there is by studying the genotoxicity of $\mathrm{Fe}_{2} \mathrm{O}_{3}, \mathrm{Al}_{2} \mathrm{O}_{3}$ and $\mathrm{Cu}$ nanoparticles in mice bone marrow.

\section{MATERIALS AND METHODS}

\section{Characterisation of nanoparticles}

The $\mathrm{Fe}_{2} \mathrm{O}_{3}(4-8 \mathrm{~nm}), \mathrm{Al}_{2} \mathrm{O}_{3}(40 \mathrm{~nm})$, and $\mathrm{Cu}(40 \mathrm{~nm})$ nanoparticles used in this study were purchased from 
Plasma Chem (Berlin, Germany) and characterised elsewhere (31). Briefly, the size and morphology of nanoparticles were observed with a transmission electron microscope (TEM) JEM-1400 (Jeol, Tokyo, Japan) at $80 \mathrm{kV}$ and 40000x magnification. Hydrodynamic radius determined with a Zetasizer Nano ZS analyser (Malvern Instruments Ltd, Malvern, UK) in extensively sonicated water suspensions of nanoparticles $(25-50 \mu \mathrm{g} / \mathrm{mL})$ showed much higher average diameter of $\mathrm{Fe}_{2} \mathrm{O}_{3}, \mathrm{Al}_{2} \mathrm{O}_{3}$, and $\mathrm{Cu}$ nanoparticles than declared $(16 \pm 5 \mathrm{~nm}, 59 \pm 8 \mathrm{~nm}$, and $51 \pm 4 \mathrm{~nm}$, respectively), most likely due to agglomeration in water (32).

\section{Animals}

Male BALB/c mice (6-7 week old) weighing $~ 22 \pm 11 \mathrm{~g}$ $(n=135)$ were obtained from the National Institute for Biotechnology and Genetic Engineering (NIBGE, Punjab, Pakistan) and kept in plastic cages (2-3 per cage) with saw dust beddings in a well-ventilated room with natural light under controlled temperature $\left(22 \pm 3{ }^{\circ} \mathrm{C}\right)$ and relative humidity $(55 \%+5 \%)$. The mice had free access to food and water and were marked with different colours for identification. All animal experiments were approved by the NIBGE Animal Care and Use Committee.

\section{Experimental design}

Table 1 details the experimental design with groups treated with different nanoparticle doses and negative and positive controls. Nanoparticle doses were selected based on our preliminary dose-response experiments. With $\mathrm{Al}_{2} \mathrm{O}_{3}$ and $\mathrm{Fe}_{2} \mathrm{O}_{3}$ nanoparticles we observed no signs of toxicity, even at the highest tested concentration of $50 \mathrm{mg} / \mathrm{kg}$ body weight (bw), but with $\mathrm{Cu}$ nanoparticles we had to lower the dose to $15 \mathrm{mg} / \mathrm{kg}$ bw, as even at $20 \mathrm{mg} / \mathrm{kg}$ bw it caused muscle tremors, paralysis, increased heart rate, hypoventilation, and coma.

Experimental doses were obtained by further dissolving $10 \mathrm{mg} / \mathrm{mL}$ stock solutions with water followed by vortexing and sonication. Doses were administered in a volume of $20 \mathrm{~mL} / \mathrm{kg}$ body weight intraperitoneally (ip) for 14 consecutive days. Intraperitoneal administration of drugs in suspension and/or nanoparticle formulations has been evidenced to result in faster and more complete absorption compared to oral and or subcutaneous routes. Furthermore, it is generally considered that systemic exposure to a substance given intraperitoneally is closer to that of the intravenous route (33).

A single ip dose of mitomycin C (2 mg/ $\mathrm{kg})$ was used as positive control in chromosome aberration (CA) and micronucleus (MN) assay. For the comet assay we used a single ip dose of methyl methanesulphonate $(100 \mathrm{mg} / \mathrm{kg})$ (both from Sigma-Aldrich, St. Louis, MO, USA) as positive control. Negative controls were injected with distilled water.

\section{Chromosome aberration assay}

The experiment followed the protocol described elsewhere (34) with slight modifications. One hour and a half before sacrifice in a chamber filled with carbon dioxide (which occurred $24 \mathrm{~h}$ after the administration of the last nanoparticle dose), the mice received a single ip dose of $2 \mathrm{mg} / \mathrm{kg}$ colchicine (Sigma-Aldrich) to arrest cell division at metaphase and their femurs were removed. Bone-marrow cells were harvested from femurs, treated with $0.56 \% \mathrm{KCl}$ hypotonic solution (Sigma-Aldrich), and kept in a water bath at $37{ }^{\circ} \mathrm{C}$ for $25 \mathrm{~min}$. Then they were centrifuged at $2000 \mathrm{~g}$ for $10 \mathrm{~min}$ and cell pellets immersed in ice-cold ethanol and acetic acid fixative (Fisher Scientific, Pittsburgh, PA, USA) $(3: 1, \mathrm{v} / \mathrm{v})$ and washed five times at 20 -min intervals. Cell pellets were then suspended in a small amount of fixative and a few drops placed on pre-cleaned and chilled microscope slides. The slides were air-dried for 3-5 min before staining with freshly prepared $5 \%$ Giemsa stain (MP Biomedicals, Hutton, CA, USA).

The slides prepared for the CA assay were also used to calculate the mitotic index (MI) by counting mitotic cells at metaphase in 1000 cells per animal (totalling 5000 cells per treatment and control groups) with a light microscope (100x magnifying oil immersed lens, Nikon, Tokyo, Japan) and multiplying them by 100 to obtain percentage $(35,36)$.

Total CAs were counted in 2500 metaphases for each treatment and controls (500 per animal).

\section{Micronucleus assay}

The MN assay followed the protocol described elsewhere $(37,38)$. Bone marrow cells were harvested using foetal calf serum $(2 \mathrm{~mL}) 24 \mathrm{~h}$ after receipt of the last dose. Cell pellets obtained by centrifugation at $300 \mathrm{~g}$ for $5 \mathrm{~min}$ were then dissolved again in about $500 \mu \mathrm{L}$ of foetal calf serum.

Two smears were prepared for each treatment and airdried prior to fixing in $90 \%$ methanol at $-20{ }^{\circ} \mathrm{C}$ for $20 \mathrm{~min}$ and staining with acridine orange (MP Biomedicals) for 2 min. After washing with phosphate buffer (Invitrogen, Carlsbad, CA, USA) twice for 3 min each, two slides per dose group were coded and scored blindly for $\mathrm{MN}$ in about 1000 reticulocytes (RETs) or polychromatic erythrocytes (PCEs) per slide at 1000x magnification under UV light using an Olympus BX50 fluorescent microscope (SouthendOn-Sea, UK). We also determined the percentage of RETs or PCEs/normochromatic erythrocytes (NCEs) per 1000 cells, as any reduction in the number of PCEs or RETs is a sign of bone marrow toxicity.

\section{Comet assay}

Bone marrow cells were harvested from femurs into a microcentrifuge tube containing $1 \mathrm{~mL}$ of cold Hank's balanced salt solution (HBSS) (Thermo Fisher Scientific, Pittsburgh, PA, USA), $0.02 \mathrm{~mol} /$ L ethylenediaminetetraacetic acid (EDTA) (Gibco-BRL, Life Technologies Ltd., 
Table 1 The experimental design for the genotoxicity assessment of $\mathrm{Al}_{2} \mathrm{O}_{3}, \mathrm{Fe}_{2} \mathrm{O}_{3}$, and Cu nanoparticles using male BALB/c mice

\begin{tabular}{|c|c|c|c|c|}
\hline Nanoparticles & Genotoxicity assay & No of animals & Groups & $\begin{array}{c}\text { Dose } \\
(\mathrm{mg} / \mathrm{kg})\end{array}$ \\
\hline \multirow{15}{*}{$\mathrm{Al}_{2} \mathbf{O}_{3}$} & \multirow{5}{*}{ Chromosomal aberration } & \multirow{5}{*}{$15=3$ per group } & $\mathrm{NC}$ & 0 \\
\hline & & & 1 & 75 \\
\hline & & & 2 & 150 \\
\hline & & & 3 & 300 \\
\hline & & & MMC (PC) & 2 \\
\hline & \multirow{5}{*}{ Micronucleus assay } & \multirow{5}{*}{$15=3$ per group } & $\mathrm{NC}$ & 0 \\
\hline & & & 1 & 75 \\
\hline & & & 2 & 150 \\
\hline & & & 3 & 300 \\
\hline & & & $\mathrm{MMC}(\mathrm{PC})$ & 2 \\
\hline & \multirow{5}{*}{ Comet assay } & \multirow{5}{*}{$15=3$ per group } & $\mathrm{NC}$ & 0 \\
\hline & & & 1 & 75 \\
\hline & & & 2 & 150 \\
\hline & & & 3 & 300 \\
\hline & & & MMS (PC) & 100 \\
\hline \multirow{15}{*}{$\mathrm{Fe}_{2} \mathrm{O}_{3}$} & \multirow{5}{*}{ Chromosomal aberration } & \multirow{5}{*}{$15=3$ per group } & $\mathrm{NC}$ & 0 \\
\hline & & & 1 & 75 \\
\hline & & & 2 & 150 \\
\hline & & & 3 & 300 \\
\hline & & & MMC (PC) & 2 \\
\hline & \multirow{5}{*}{ Micronucleus assay } & \multirow{5}{*}{$15=3$ per group } & $\mathrm{NC}$ & 0 \\
\hline & & & 1 & 75 \\
\hline & & & 2 & 150 \\
\hline & & & 3 & 300 \\
\hline & & & MMC (PC) & 2 \\
\hline & \multirow{5}{*}{ Comet assay } & \multirow{5}{*}{$15=3$ per group } & $\mathrm{NC}$ & 0 \\
\hline & & & 1 & 75 \\
\hline & & & 2 & 150 \\
\hline & & & 3 & 300 \\
\hline & & & MMS (PC) & 100 \\
\hline \multirow{15}{*}{$\mathrm{Cu}$} & \multirow{5}{*}{ Chromosomal aberration } & \multirow{5}{*}{$15=3$ per group } & $\mathrm{NC}$ & 0 \\
\hline & & & 1 & 5 \\
\hline & & & 2 & 10 \\
\hline & & & 3 & 15 \\
\hline & & & MMC (PC) & 2 \\
\hline & \multirow{5}{*}{ Micronucleus assay } & \multirow{5}{*}{$15=3$ per group } & $\mathrm{NC}$ & 0 \\
\hline & & & 1 & 5 \\
\hline & & & 2 & 10 \\
\hline & & & 3 & 15 \\
\hline & & & MMC (PC) & 2 \\
\hline & \multirow{5}{*}{ Comet assay } & \multirow{5}{*}{$15=3$ per group } & $\mathrm{NC}$ & 0 \\
\hline & & & 1 & 5 \\
\hline & & & 2 & 10 \\
\hline & & & 3 & 15 \\
\hline & & & MMS (PC) & 100 \\
\hline
\end{tabular}


Inchinnan, UK), and $10 \%$ dimethyl sulphoxide (DMSO) (Thermo Fisher Scientific). Bone marrow suspension was filtered with a $40 \mu \mathrm{m}$ cell strainer into $15 \mathrm{~mL}$ conical tubes on ice. The alkaline comet assay followed the procedure described elsewhere $(39,40)$. Briefly, we prepared a mixture of single-cell suspension $(100 \mu \mathrm{L})$ containing approximately $2 \times 10^{6}$ cells $/ \mathrm{mL}$ and $1 \%$ low melting point agarose (LMA) (Promega Corporation, Madison, WI, USA) with $900 \mu \mathrm{L}$ of phosphate buffer saline (Gibco-BRL) and spread $200 \mu \mathrm{L}$ of the mixture over microscope slides precoated with $1 \%$ normal melting point agarose (NMA) (Invitrogen Life Technologies Ltd., Paisley, UK) and then covered the slides with a cover slip. The slides were left to solidify at $4{ }^{\circ} \mathrm{C}$ for $30 \mathrm{~min}$ and then the cover slips were removed. Two slides were prepared for each sample.

Slides were immersed into a fresh cold lysis solution prepared at least one hour in advance of use and containing $2.5 \mathrm{~mol} / \mathrm{L} \mathrm{NaCl}$ (Sigma-Aldrich), $0.1 \mathrm{~mol} / \mathrm{L}$ EDTA, $10 \%$ DMSO, 1 \% Triton X-100 (Applichem GmbH, Darmstadt, Germany), and $0.01 \mathrm{~mol} / \mathrm{L}$ Tris-HCl (Merck, Whitehouse Station, NJ, USA) or $\mathrm{NaOH}$ (Sigma-Aldrich) to adjust it to $\mathrm{pH}$ 10. Following lysis, the slides were placed into a chilled alkaline solution $(0.3 \mathrm{~mol} / \mathrm{L} \mathrm{NaOH}$ and $0.001 \mathrm{~mol} / \mathrm{L}$ EDTA, $\mathrm{pH}>13$ ) for $40 \mathrm{~min}$ to get DNA unwound. Then they were subjected to electrophoresis (in the same alkaline solution) at $0.8 \mathrm{~V} / \mathrm{cm}, \sim 300 \mathrm{~mA}$, and $4{ }^{\circ} \mathrm{C}$ in the dark for $30 \mathrm{~min}$ and neutralised to $\mathrm{pH} 7.5$ with $0.4 \mathrm{~mol} / \mathrm{L}$ Tris $\mathrm{HCl}$ three times for 5 min each. After fixing with ice cold ethanol (100\%) and staining with $20 \mu \mathrm{g} / \mathrm{mL}$ ethidium bromide (SigmaAldrich), the slides were left to dry overnight.

A total of 50 comets were scored visually at $40 x$ magnification with an epifluorescence microscope (LB201, Labomed Inc., Los Angeles, CA, USA) on each of the two slides per dose. Total score ranged between 0 (no detectable damage) and 400 (maximum damage) according to the method described by Collins (41), as follows:

$\mathrm{AU}_{\mathrm{T}}=\mathrm{N}_{0} \times 0+\mathrm{N}_{1} \times 1+\mathrm{N}_{2} \times 2+\mathrm{N}_{3} \times 3+\mathrm{N}_{4} \times 4$

where $\mathrm{AU}_{\mathrm{T}}$ are arbitrary units and $\mathrm{N}_{0}, \mathrm{~N}_{1}, \mathrm{~N}_{2}, \mathrm{~N}_{3}$, and $\mathrm{N}_{4}$ are the number of cells scored in each group $(0,1,2,3$, and 4 , respectively). The results from three independent experiments were averaged to obtain $\mathrm{AU}_{\mathrm{T}}$ for each treatment (42).

\section{Enzyme-modified comet assay}

To detect oxidative damage to DNA bases we used the human 8-hydroxyguanine DNA-glycosylase (hOGG1) and endonuclease III (EndoIII) modified comet assay as described elsewhere (41). Briefly, the assay followed the same experimental steps as the standard comet assay, except that, following lysis, the slides were washed with enzyme buffer instead containing $0.04 \mathrm{~mol} / \mathrm{L} \mathrm{N}$-(2-hydroxyethyl) piperazine-N'-2-ethanesulphonic acid (HEPES), $0.1 \mathrm{~mol} / \mathrm{L}$ $\mathrm{KCl}, 5 \mathrm{mmol} / \mathrm{L}$ EDTA, $0.2 \mathrm{mg} / \mathrm{mL}$ bovine serum albumin (BSA) (Sigma-Aldrich), and $\mathrm{KOH}$ (Merck) to adjust $\mathrm{pH}$ to 8.0 .
After washing, two slides from each dose group were treated with $200 \mu \mathrm{L}$ of buffer (without enzyme as negative control), $200 \mu \mathrm{L}$ of enzyme buffer containing $1.6 \mathrm{U} /$ mLhOGG1 (1:1000), and $200 \mu \mathrm{L}$ of enzyme buffer containing $10 \mathrm{U} / \mathrm{mL}$ Endo III (1:1000) (New England Biolabs Ltd., Hitchin, UK). The slides were then incubated at $37^{\circ} \mathrm{C}$ for $45 \mathrm{~min}$.

After enzyme treatment, the DNA unwinding, electrophoresis, neutralisation, staining, and scoring of damaged DNA were performed in the same way as described above for the standard comet assay. The slides without enzyme treatment (negative control) served to estimate the background level of DNA strand breaks (SB) $(43,44)$.

\section{Statistical analysis}

Statistical analysis was run on Minitab version 16 (Minitab Inc., State College, PA, USA). One-way analysis of variance (ANOVA) and Tukey's range test were used to establish significant $(\mathrm{P}<0.05)$ differences between the control groups and treatment groups.

\section{RESULTS AND DISCUSSION}

Consistently through all our measurements, only the highest dose of $\mathrm{Cu}$ nanoparticles $(15 \mathrm{mg} / \mathrm{kg})$ caused significant changes in chromosome aberrations (Table 2), mitotic index (Table 3), micronucleus frequency (Figures $1 \& 2$ ), reticulocyte frequency (Figures $3 \& 4$ ), and DNA damage (Figures 5-7) compared to negative control.

This is in line with a number of in vitro and in vivo studies showing no damaging effects of $\mathrm{Al}_{2} \mathrm{O}_{3}$ and $\mathrm{Fe}_{2} \mathrm{O}_{3}$ nanoparticles in a variety of doses, administration routes (oral, inhalation), and matrices (monkey kidney cells, bone marrow, colon cells, human peripheral blood lymphocytes, or Syrian hamster embryonic cells $(31,45-50)$. The only exception are the genotoxic effects reported in peripheral blood of rats exposed to $\mathrm{Al}_{2} \mathrm{O}_{3}$ nanoparticles at doses above $1000 \mathrm{mg} / \mathrm{kg}$ through oral gavage (9).

As for the adverse effects of $\mathrm{Cu}$ nanoparticles at the highest ip dose of $15 \mathrm{mg} / \mathrm{kg}$ bw, our results are supported by two studies reporting damage to red blood cells, thymus, spleen, liver, and kidney caused by $\mathrm{Cu}$ nanoparticles (51) and changes in haematological parameters and liver damage caused by $\mathrm{CuO}$ nanoparticles in rats (52). One in vivo study with $\mathrm{CuO}$ nanoparticles showed $\mathrm{MN}$ formation in reticulocytes and increased 8-hydroxy-2'-deoxyguanosine levels in urine and liver DNA owed to oxidative stress (38). Another study with $\mathrm{Cu}$ nanoparticles showed antimicrobial effects in the caecum, and liver damage (53). Our findings are also in line with a report of serious kidney, liver, and spleen injuries in mice exposed to $\mathrm{Cu}$ nanoparticles (54). In fact, thanks to their higher toxicity, $\mathrm{Cu}$ nanoparticles have been considered for anticancer treatment, as they seem to cause cellular apoptosis, DNA degradation, chromosome 




Figure 1 Reticulocyte micronucleus frequency (\%MN-RETs) in mice treated with $\mathrm{Fe}_{2} \mathrm{O}_{3}$ or $\mathrm{Al}_{2} \mathrm{O}_{3}$ nanoparticles and a single dose of mitomycin $\mathrm{C}(\mathrm{MMC}) .{ }^{*}$ significant difference $(\mathrm{P}<0.05)$ from negative control $(0)$

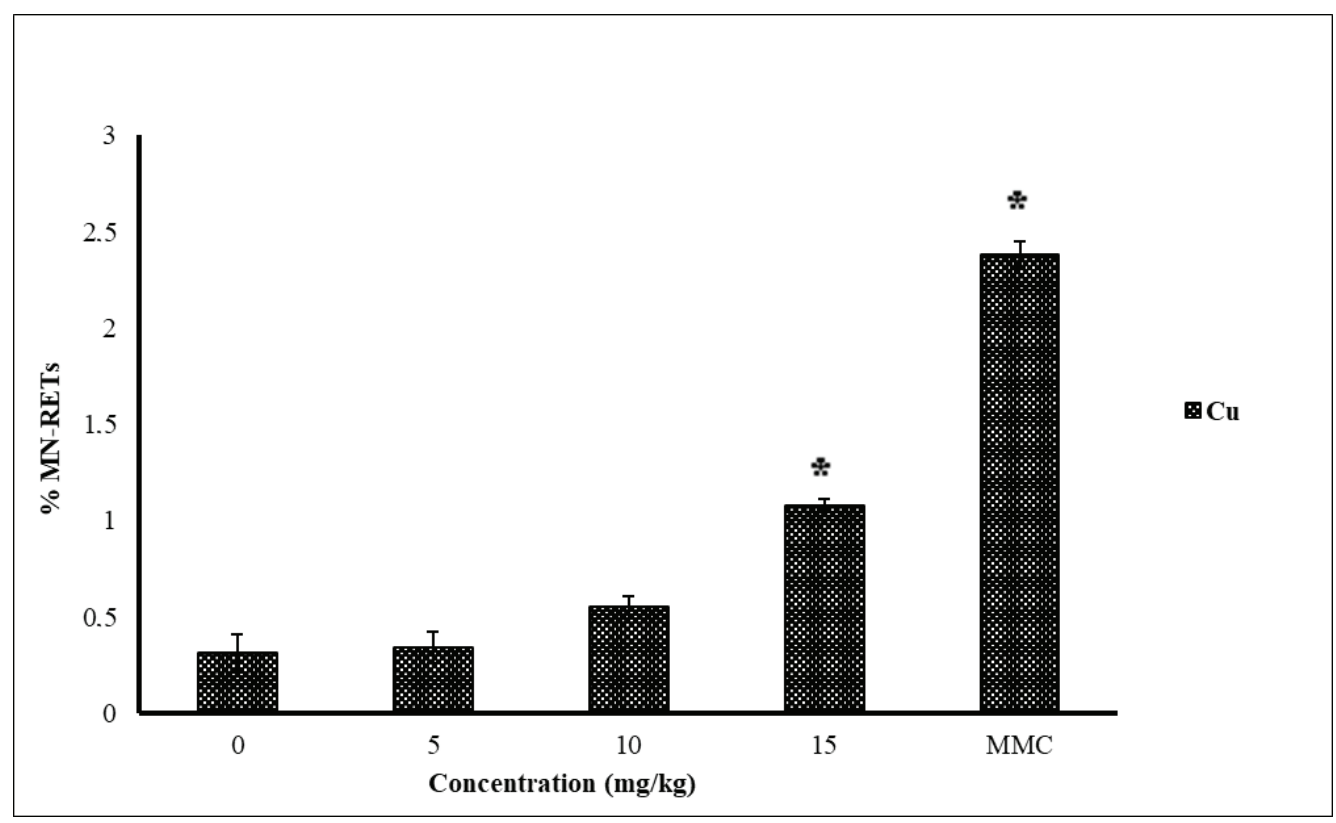

Figure 2 Reticulocyte micronucleus frequency (\%MN-RETs) in mice treated with Cu nanoparticles and a single dose of mitomycin $\mathrm{C}(\mathrm{MMC})$. * significant difference $(\mathrm{P}<0.05)$ from negative control $(0)$ 
Table 2 Chromosomal aberrations in bone marrow cells of male BALB/c mice treated with $\mathrm{Fe}_{2} \mathrm{O}_{3}, \mathrm{Al}_{2} \mathrm{O}_{3}$ and $\mathrm{Cu}$ nanoparticles

\begin{tabular}{|c|c|c|c|c|c|c|c|c|}
\hline \multirow{2}{*}{ Group } & \multirow{2}{*}{$\begin{array}{c}\text { Dose } \\
(\mathrm{mg} / \mathrm{kg})\end{array}$} & \multirow{2}{*}{$\begin{array}{l}\text { No. of analysed } \\
\text { metaphases }\end{array}$} & \multicolumn{4}{|c|}{ Chromosomal aberrations } & \multirow{2}{*}{ TA/500 cells } & \multirow{2}{*}{$\begin{array}{c}\text { CA/cell } \\
\text { Mean } \pm \text { SD }\end{array}$} \\
\hline & & & CtB & ChB & CtG & ChG & & \\
\hline \multicolumn{9}{|c|}{$\mathrm{Fe}_{2} \mathrm{O}_{3}$ nanoparticles } \\
\hline $\mathrm{NC}$ & 0 & 500 & 18 & 13 & 14 & 15 & 60 & $0.120 \pm 0.026$ \\
\hline $\mathrm{PC}$ & 2 & 500 & 106 & 35 & 104 & 60 & 305 & $0.610 \pm 0.081 *$ \\
\hline 1 & 75 & 500 & 21 & 10 & 35 & 15 & 89 & $0.178 \pm 0.057$ \\
\hline 2 & 150 & 500 & 20 & 12 & 38 & 10 & 86 & $0.172 \pm 0.023$ \\
\hline 3 & 300 & 500 & 27 & 09 & 40 & 16 & 92 & $0.184 \pm 0.029$ \\
\hline \multicolumn{9}{|c|}{$\mathrm{Al}_{2} \mathrm{O}_{3}$ nanoparticles } \\
\hline $\mathrm{NC}$ & 0 & 500 & 14 & 16 & 11 & 17 & 58 & $0.116 \pm 0.019$ \\
\hline $\mathrm{PC}$ & 2 & 500 & 102 & 41 & 115 & 53 & 311 & $0.622 \pm 0.147 *$ \\
\hline 1 & 75 & 500 & 20 & 13 & 38 & 12 & 83 & $0.166 \pm 0.081$ \\
\hline 2 & 150 & 500 & 15 & 10 & 43 & 10 & 79 & $0.158 \pm 0.046$ \\
\hline 3 & 300 & 500 & 19 & 14 & 40 & 11 & 89 & $0.168 \pm 0.039$ \\
\hline \multicolumn{9}{|c|}{ Cu nanoparticles } \\
\hline $\mathrm{NC}$ & 0 & 500 & 15 & 12 & 18 & 16 & 61 & $0.12 \pm 0.037$ \\
\hline $\mathrm{PC}$ & 2 & 500 & 98 & 35 & 110 & 61 & 304 & $0.608 \pm 0.081 *$ \\
\hline 1 & 5 & 500 & 20 & 13 & 22 & 15 & 70 & $0.140 \pm 0.054$ \\
\hline 2 & 10 & 500 & 19 & 14 & 20 & 16 & 69 & $0.138 \pm 0.048$ \\
\hline 3 & 15 & 500 & 50 & 26 & 68 & 41 & 185 & $0.370 \pm 0.076 *$ \\
\hline
\end{tabular}

Data are expressed as means $\pm \mathrm{SD}(\mathrm{n}=5)$. * significant difference from negative control $(\mathrm{P}<0.05) ; \mathrm{NC}$ - negative control; $\mathrm{PC}$ - positive control (single ip dose of $2 \mathrm{mg} / \mathrm{kg}$ mitomycin $\mathrm{C}$ ); $\mathrm{TA}$ - total number of aberrant cells; $\mathrm{CtB}$ - chromatid breaks; $\mathrm{ChB}$ - chromosome breaks; $\mathrm{CtG}$ - chromatid gaps; $\mathrm{ChG}$ - chromosome gaps

Table 3 Mitotic index in bone marrow cells of male BALB/c mice treated with $\mathrm{Fe}_{2} \mathrm{O}_{3}, \mathrm{Al}_{2} \mathrm{O}_{3}$, and $\mathrm{Cu}$ nanoparticles

\begin{tabular}{|c|c|c|c|c|}
\hline Group & $\begin{array}{c}\text { Dose } \\
(\mathrm{mg} / \mathrm{kg})\end{array}$ & $\begin{array}{l}\text { No. of analysed } \\
\text { metaphases }\end{array}$ & No. of mitotic cells & $\begin{array}{c}\text { Mitotic index } \\
(\%)\end{array}$ \\
\hline \multicolumn{5}{|c|}{$\mathrm{Fe}_{2} \mathrm{O}_{3}$ nanoparticles } \\
\hline $\mathrm{NC}$ & 0 & 5000 & 409 & $8.180 \pm 0.540$ \\
\hline $\mathrm{PC}$ & 2 & 5000 & 61 & $1.220 \pm 0.259 *$ \\
\hline 1 & 75 & 5000 & 399 & $7.980 \pm 0.370$ \\
\hline 2 & 150 & 5000 & 395 & $7.900 \pm 0.709$ \\
\hline 3 & 300 & 5000 & 401 & $8.080 \pm 1.180$ \\
\hline \multicolumn{5}{|c|}{$\mathrm{Al}_{2} \mathrm{O}_{3}$ nanoparticles } \\
\hline $\mathrm{NC}$ & 0 & 5000 & 417 & $8.340 \pm 0.351$ \\
\hline $\mathrm{PC}$ & 2 & 5000 & 58 & $1.160 \pm 0.288^{*}$ \\
\hline 1 & 75 & 5000 & 403 & $8.060 \pm 0.517$ \\
\hline 2 & 150 & 5000 & 409 & $8.180 \pm 0.687$ \\
\hline 3 & 300 & 5000 & 399 & $7.980 \pm 0.991$ \\
\hline \multicolumn{5}{|c|}{ Cu nanoparticles } \\
\hline $\mathrm{NC}$ & 0 & 5000 & 411 & $8.220 \pm 0.277$ \\
\hline $\mathrm{PC}$ & 2 & 5000 & 54 & $1.080 \pm 0.238^{*}$ \\
\hline 1 & 5 & 5000 & 406 & $8.120 \pm 0.868$ \\
\hline 2 & 10 & 5000 & 399 & $7.980 \pm 0.673$ \\
\hline 3 & 15 & 5000 & 309 & $6.180 \pm 0.802 *$ \\
\hline
\end{tabular}

Data are expressed as means $\pm \mathrm{SD}(\mathrm{n}=5)$. * significant difference from negative control $(\mathrm{P}<0.05)$; Mitotic index $(\%)-$ number of mitotic cells per total number of cells observed $\times 100 ; \mathrm{NC}$ - negative control; $\mathrm{PC}$ - positive control (single ip dose of $2 \mathrm{mg} / \mathrm{kg}$ mitomycin C) 


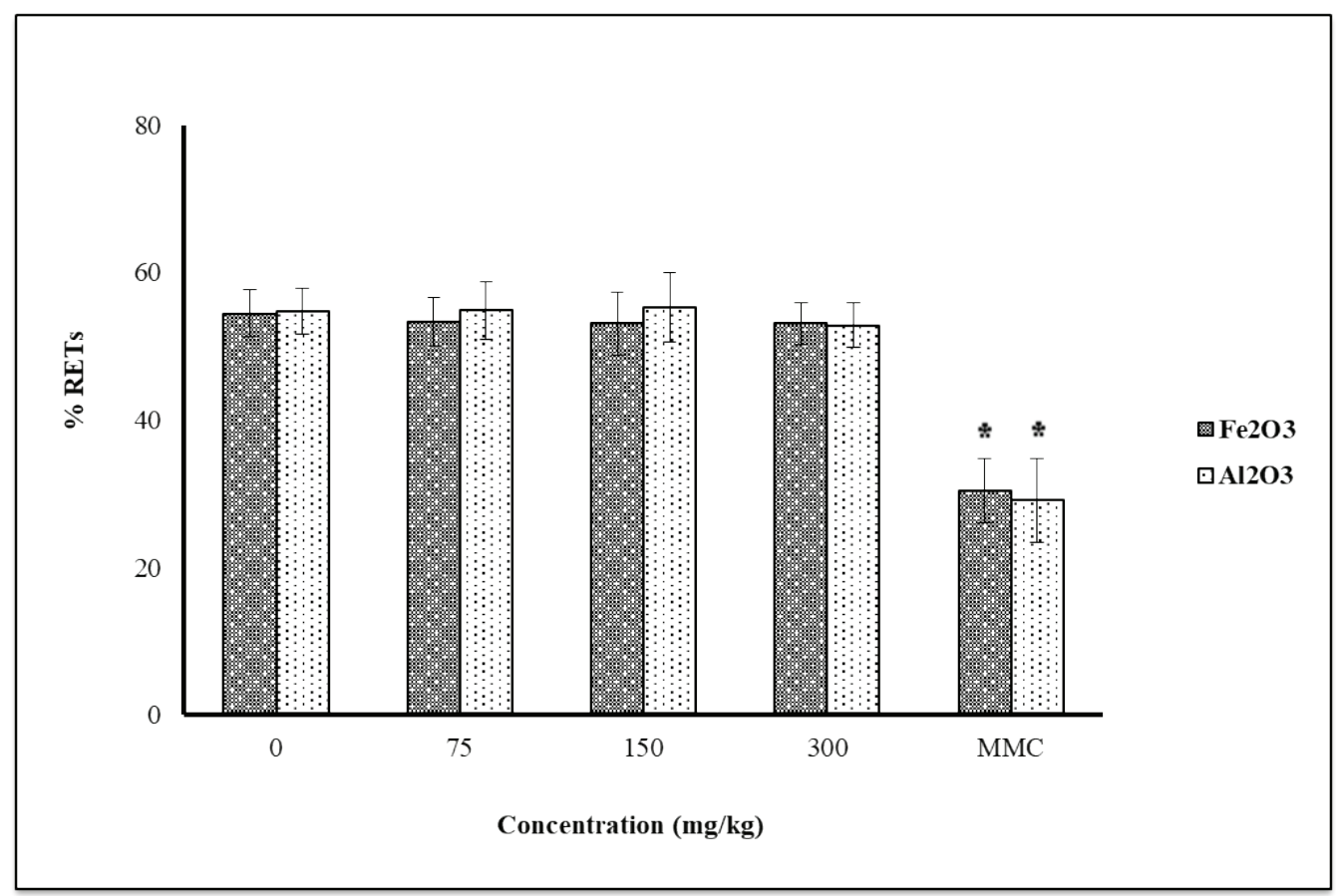

Figure 3 Reticulocyte frequency (\%RETs) in mice treated with $\mathrm{Fe}_{2} \mathrm{O}_{3}$ or $\mathrm{Al}_{2} \mathrm{O}_{3}$ nanoparticles and a single dose of mitomycin $\mathrm{C}$ (MMC). *significant difference $(\mathrm{P}<0.05)$ from negative control $(0)$

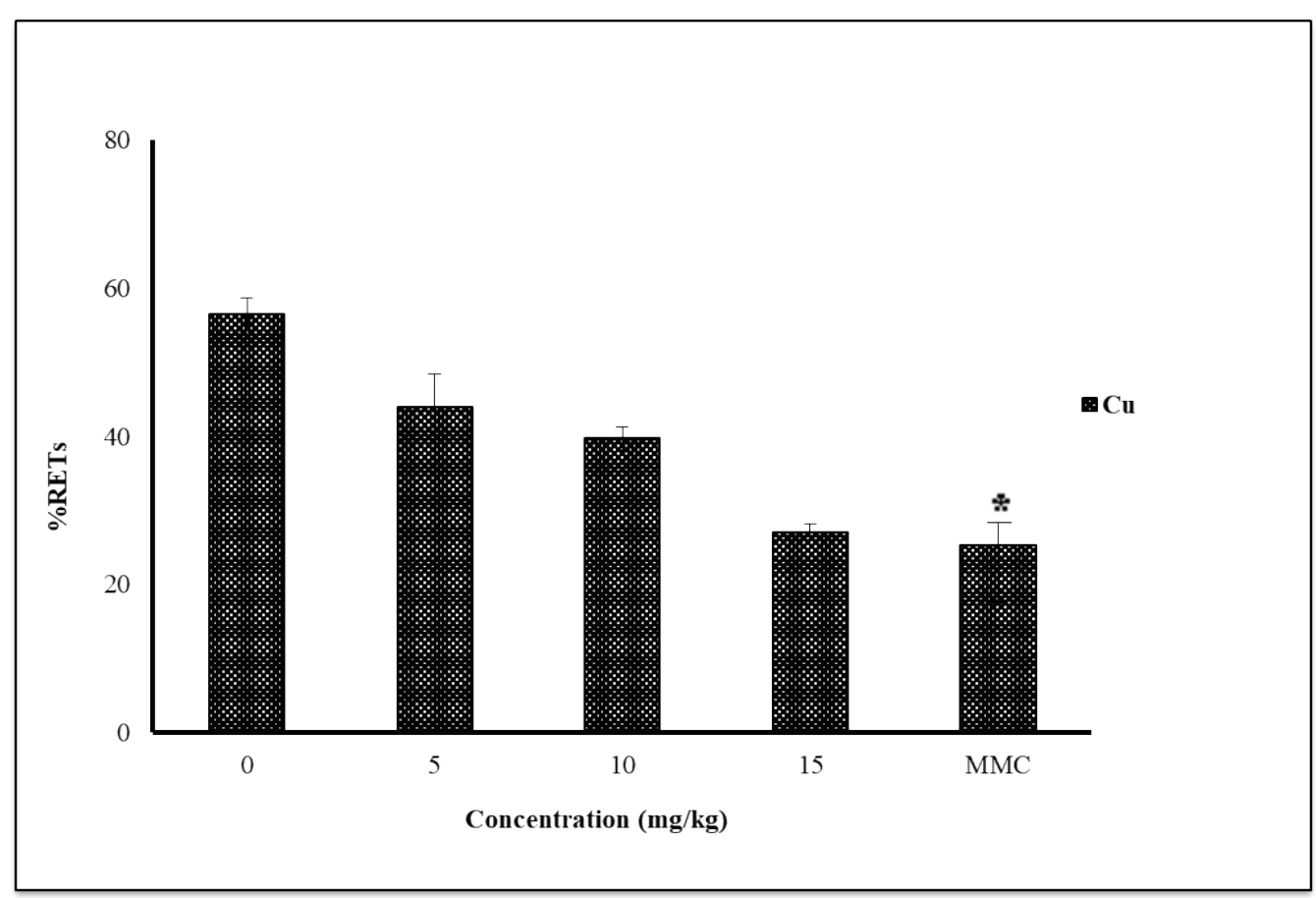

Figure 4 Reticulocyte frequency (\%RET) in mice treated with $\mathrm{Cu}$ nanoparticles and a single dose of mitomycin $\mathrm{C}$ (MMC). *significant difference $(\mathrm{P}<0.05)$ from negative control $(0)$ 




Figure 5 DNA damage induced by $\mathrm{Al}_{2} \mathrm{O}_{3}$ nanoparticles in mice bone marrow measured by the standard and enzyme-modified comet assays. * significant difference $(\mathrm{P}<0.05)$ from negative control. EndoIII - endonuclease III-modified comet assay; hOGG1 - human 8-hydroxyguanine DNA-glycosylase-modified comet assay; MMS - methyl methanesulphonate. Note: the reason for low hOGG1 findings with MMS is that it cannot detect alkylating damage caused by it (43)

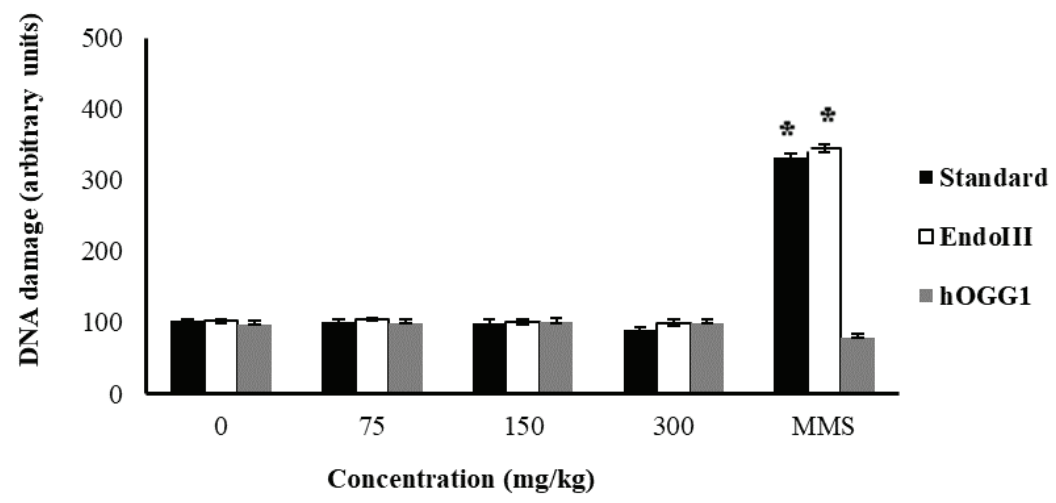

Figure 6 DNA damage induced by $\mathrm{Fe}_{2} \mathrm{O}_{3}$ nanoparticles in mice bone marrow measured by the standard and enzyme-modified comet assays. * significant difference $(\mathrm{P}<0.05)$ from negative control. EndoIII - endonuclease III-modified comet assay; hOGG1 - human 8-hydroxyguanine DNA-glycosylase-modified comet assay; MMS - methyl methanesulphonate. Note: the reason for low hOGG1 findings with MMS is that it cannot detect alkylating damage caused by it (43)

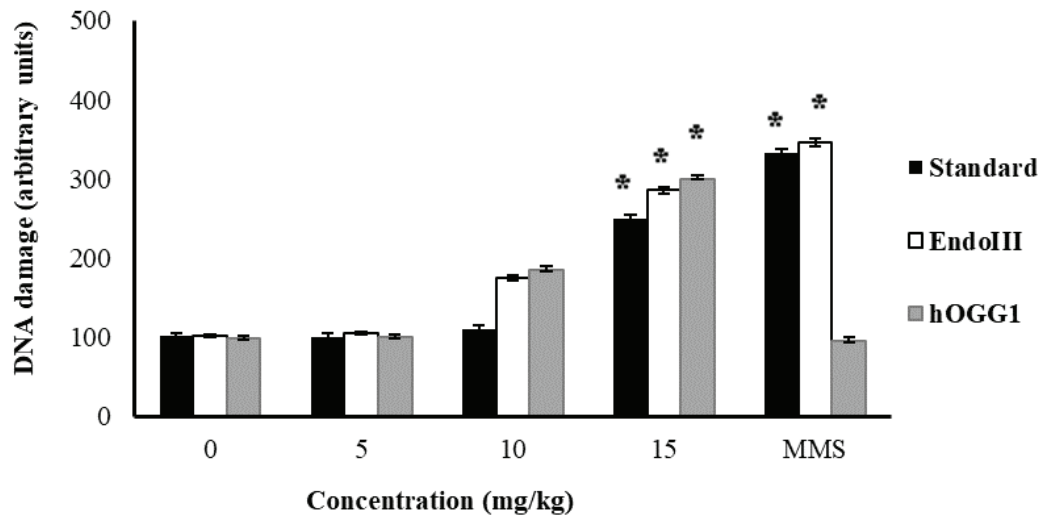

Figure 7 DNA damage induced by $\mathrm{Cu}$ nanoparticles in mice bone marrow measured by the standard and enzyme-modified comet assays. * significant difference $(\mathrm{P}<0.05)$ from negative control. EndoIII - endonuclease III-modified comet assay; hOGG1 - human 8-hydroxyguanine DNA-glycosylase-modified comet assay; MMS - methyl methanesulphonate. Note: the reason for low hOGG1 findings with MMS is that it cannot detect alkylating damage caused by it (43) 
condensation, cell cycle inhibition, depolarisation of the mitochondrial membrane, and lowering of cell membrane rigidity in skin melanoma A-375 cells (55).

What sets our study apart from great many in vivo studies of the kind - which look into biodistribution, accumulation, changes in body and organ weight, pathological and neurodevelopmental changes, liver, kidney, heart, and lung toxicity, and damage to immune system (56-69) - is that it looks into genotoxic potentials of these nanoparticles and sets up a highly suitable and sensitive combination of assays to monitor in vivo genotoxicity of different nanoparticles using mice as model organism. We believe that these bioassays should be included as important tools for nanoparticle toxicity and risk assessment before their use in consumer product and subsequent release into the environment.

\section{Acknowledgements}

The authors are thankful to Higher Education Commission (HEC), Pakistan, for providing financial support.

\section{Conflicts of interest}

None to declare.

\section{REFERENCES}

1. Oberdörster G, Oberdörster E, Oberdörster J. Nanotoxicology: an emerging discipline evolving from studies of ultrafine particles. Environ Health Perspect 2005;113:823-39. doi: 10.1289/ehp.7339

2. Amoabediny G, Naderi A, Malakootikhah J, Koohi MK, Mortazavi SA, Naderi M, Rashedi H. Guidelines for safe handling, use and disposal of nanoparticles. J Phys Conf Ser 2009;170:012037-50. doi: 10.1088/1742-6596/170/1/012037

3. Ahamed M, Karns M, Goodson M, Rowe J, Hussain SM, Schlager JJ, Hong Y. DNA damage response to different surface chemistry of silver nanoparticles in mammalian cells. Toxicol Appl Pharmacol 2008;233:404-10. doi: 10.1016/j. taap.2008.09.015

4. Singh N, Manshian B, Jenkins GJ, Griffiths SM, Williams PM, Maffeis TG, Wright CJ, Doak SH. NanoGenotoxicology: the DNA damaging potential of engineered nanomaterials. Biomaterials 2009;30:3891-914. doi : biomaterials.2009.04.009

5. Buzea C, Pacheco II, Robbie K. Nanomaterials and nanoparticles: sources and toxicity. Bio interphases 2007;2:MR17-71. doi: 10.1116/1.2815690

6. Hassanpour P, Panahi Y, Ebrahimi-Kalan A, Akbarzadeh A, Davaran S, Nasibova AN, Khalilov R, Kavetskyy T. Biomedical applications of aluminium oxide nanoparticles. Micro Nano Lett 2018;13:1227-31. doi: 10.1049/ mnl.2018.5070

7. Ghaemi, N. A new approach to copper ion removal from water by polymeric nanocomposite membrane embedded with $\gamma$-alumina nanoparticles. Appl Surf Sci 2016;364:2218. doi: 10.1016/j.apsusc.2015.12.109
8. Zhao G, Wu X, Tan X, Wang X. Sorption of heavy metal ions from aqueous solutions: A review. Open Colloid Sci J 2010;4:19-31. doi: 10.2174/1876530001104010019

9. Balasubramanyam A, Sailaja N, Mahboob M, Rahman MF, Hussain SM, Grover P. In vivo genotoxicity assessment of aluminium oxide nanomaterials in rat peripheral blood cells using the comet assay and micronucleus test. Mutagenesis 2009;24:245-51. doi: 10.1093/mutage/gep003

10. Prabhakara P V, Reddya UA, Singha SP, Balasubramanyam A, Rahman MF, Indu Kumari S, Agawane SB, Murty US, Grover P, Mahboob M. Oxidative stress induced by aluminum oxide nanomaterials after acute oral treatment in Wistar rats. J Appl Toxicol 2012;32:436-45. doi: 10.1002/jat.1775

11. Dey S, Bakthavatchalu V, Tseng MT, Wu P, Florence RL, Grulke EA, Yokel RA, Dhar SK, Yang HS, Chen Y, St Clair DK. Interactions between SIRT1 and AP-1 reveal a mechanistic insight into the growth promoting properties of alumina $\left(\mathrm{Al}_{2} \mathrm{O}_{3}\right)$ nanoparticles in mouse skin epithelial cells. Carcinogenesis 2008;29:1920-9. doi: 10.1093/carcin/bgn175

12. Oesterling E, Chopra N, Gavalas V, Arzuaga X, Lim EJ, Sultana R, Butterfield DA, Bachas L, Hennig B. Alumina nanoparticles induce expression of endothelial cell adhesion molecules. Toxicol Lett 2008;178:160-6. doi: 10.1016/j. toxlet.2008.03.011

13. Chen L, Yokel RA, Hennig B, Toborek M. Manufactured aluminum oxide nanoparticles decrease expression of tight junction proteins in brain vasculature. J Neuroimmune Pharmacol 2008;3:286-95. doi: 10.1007/s11481-008-91315

14. Rosenblum LT, Kosaka N, Mitsunaga M, Choyke PL, Kobayashi $\mathrm{H}$. In vivo molecular imaging using nanomaterials: general in vivo characteristics of nano-sized reagents and applications for cancer diagnosis. Mol Membr Biol 2010;27:274-85. doi: 10.3109/09687688.2010.481640

15. Peng XH, Qian X, Mao H, Wang AY, Chen ZG, Nie S, Shin DM. Targeted magnetic iron oxide nanoparticles for tumor imaging and therapy. Int J Nanomedicine 2008;3:311-21. doi: $10.2147 /$ ijn. s2824

16. Thorek DL, Chen AK, Czupryna J, Tsourkas A. Superparamagnetic iron oxide nanoparticle probes for molecular imaging. Ann Biomed Eng 2006;34:23-38. doi: 10.1007/s10439-005-9002-7

17. Cherukuri P, Glazer ES, Curley SA. Targeted hyperthermia using metal nanoparticles. Adv Drug Deliv Rev 2010;62:339 45. doi: 10.1016/j.addr.2009.11.006

18. Dhakshinamoorthy V, Manickam V, Perumal E. Neurobehavioural toxicity of iron oxide nanoparticles in mice. Neurotox Res 2017;32:187-203. doi: 10.1007/s12640017-9721-1

19. Sundarraj K, Raghunath A, Panneerselvam L, Perumal E. Iron oxide nanoparticles modulate heat shock proteins and organ specific markers expression in mice male accessory organs. Toxicol Appl Pharmacol 2017;317:12-24. doi: 10.1016/j.taap.2017.01.002

20. Ansari MO, Parveen N, Ahmad MF, Wani AL, Afrin S, Rahman Y, Jameel S, Khan YA, Siddique HR, Tabish M, Shadab GGHA. Evaluation of DNA interaction, genotoxicity and oxidative stress induced by iron oxide nanoparticles both in vitro and in vivo: attenuation by thymoquinone. Sci Rep 2019;9:6912-26. doi: 10.1038/s41598-019-43188-5

21. Liu G, Li X, Qin B, Xing D, Guo Y, Fan R . Investigation of the mending effect and mechanism of copper nano-particles 
on a tribologically stressed surface. Tribol Lett 2004;17:9616. doi: 10.1007/S11249-004-8109-6

22. Palza H. Antimicrobial polymers with metal nanoparticles. Int J Mol Sci 2015;16:2099-116. doi: 10.3390/ijms16012099

23. Colomban P. The use of metal nanoparticles to produce yellow, red and iridescent colour, from Bronze Age to present times in lustre pottery and glass: solid state chemistry, spectroscopy and nanostructure. J Nano Res 2009;8:109-32. doi: 10.4028/www.scientific.net/JNanoR.8.109

24. Polino G, Abbel R, Shanmugam S, Bex GJP, Hendriks R, Brunetti F, Di Carlo A, Andriessen R, Galagan Y. A benchmark study of commercially available copper nanoparticle inks for application in organic electronic devices. Org Electron 2016;34:130-8. doi: 10.1016/j. orgel.2016.04.021

25. Kanhed P, Birla S, Gaikwad S, Gade A, Seabra AB, Rubilar O, Duran N, Rai M. In vitro antifungal efficacy of copper nanoparticles against selected crop pathogenic fungi. Mater Lett 2014;115:13-7. doi: 10.1016/j.matlet.2013.10.011

26. Ren G, Hu D, Cheng EW, Vargas-Reus MA, Reip P, Allaker RP. Characterisation of copper oxide nanoparticles for antimicrobial applications. Int J Antimicrob Agents 2009;33:587-90. doi: 10.1016/j.ijantimicag.2008.12.004

27. Lei R, Wu C, Yang B, Ma H, Shi C, Wang Q, Wang Q, Yuan Y, Liao M. Integrated metabolomic analysis of the nano-sized copper particle-induced hepatotoxicity and nephrotoxicity in rats: A rapid in vivo screening method for nanotoxicity Toxicol Appl Pharmacol 2008;232:292-301. doi: 10.1016/j. taap.2008.06.026

28. Karlsson HL, Gustafsson J, Cronholm P, Möller L. Sizedependent toxicity of metal oxide particles: a comparison between nano- and micrometer size. Toxicol Lett 2009;188:112-8. doi: 10.1016/j.toxlet.2009.03.014

29. Alarifi S, Ali D, Verma A, Alakhtani S, Ali BA. Cytotoxicity and genotoxicity of copper oxide nanoparticles in human skin keratinocytes cells. Int J Toxicol 2013;32:296-307. doi: 10.1177/1091581813487563

30. Zhang CH, Wang Y, Sun QQ, Xia LL, Hu JJ, Cheng K, Wang $\mathrm{X}, \mathrm{Fu} \mathrm{XX}, \mathrm{Gu} \mathrm{H}$. Copper nanoparticles show obvious in vitro and in vivo reproductive toxicity via ERK mediated signaling pathway in female mice. Int J Biol Sci 2018;14:1834-44. doi: 10.7150/ijbs. 27640

31. Sadiq R, Khan QM, Mobeen A, Hashmat AJ. In vitro toxicological assessment of iron oxide, aluminium oxide and copper nanoparticles in prokaryotic and eukaryotic cell types. Drug Chem Toxicol 2014;38:152-61. doi: 10.3109/01480545.2014.919584

32. Murdock RC, Braydich-Stolle L, Schrand AM, Schlager JJ, Hussain SM. Characterization of nanomaterial dispersion in solution prior to in vitro exposure using dynamic light scattering technique. Toxicol Sci 2008;101:239-53. doi: 10.1093/toxsci/kfm240

33. Al Shoyaib A, Archie, SR, Karamyan VT. Intraperitoneal route of drug administration: should it be used in experimental animal studies? Pharm Res 2020;37:12. doi: org/10.1007/ s11095-019-2745-x

34. Preston RJ, Dean BJ, Galloway S, Holden H, McFee AF, Shelby M. In vivo cytogenetic assays: Analysis of chromosome aberrations in bone marrow cells. Mutat Res 1987;189:15765. doi: 10.1016/0165-1218(87)90021-8

35. Pérez Martín JM, Fernández Freire P, Labrador V, Hazen MJ. Carbamazepine induces mitotic arrest in mammalian Vero cells. Mutat Res 2008;637:124-33. doi: 10.1016/j. mrfmmm.2007.07.014

36. Patlolla AK, Patra PK, Flountan M, Tchounwou PB. Cytogenetic evaluation of functionalized single-walled carbon nanotube in mice bone marrow cells. Environ Toxicol 2016;31:1091-102. doi: 10.1002/tox.22118

37. Schmid W. The micronucleus test. Mutat Res 1975;31:9-15. doi: 10.1016/0165-1161(75)90058-8

38. Song MF, Li YS, Kasai H, Kawai K. Metal nanoparticleinduced micronuclei and oxidative DNA damage in mice. $\mathrm{J}$ Clin Biochem Nutr 2012;50:211-6. doi: 10.3164/jcbn.11-70

39. Singh NP, McCoy MT, Tice RR, Schneider EL. A simple technique for quantitation of low levels of DNA damage in individual cells. Exp Cell Res 1988;175:184-91. doi: 10.1016/0014-4827(88)90265-0

40. Li Y, Bhalli JA, Ding W, Yan J, Pearce MG, Sadiq R, Cunningham CK, Jones MY, Monroe WA, Howard PC, Zhou T, Chen T. Cytotoxicity and genotoxicity assessment of silver nanoparticles in mouse. Nanotoxicology 2014;8(Suppl 1):36-45. doi: 10.3109/17435390.2013.855827

41. Collins AR. The comet assay for DNA damage and repair: principles, applications, and limitations. Mol Biotechnol 2004;26:249-61. doi: 10.1385/MB:26:3:249

42. Woodruff RS, Li Y, Yan J, Bishop M, Jones MY, Watanabe F, Biris AS, Rice P, Zhou T, Chen T. Genotoxicity evaluation of titanium dioxide nanoparticles using the Ames test and Comet assay. J Appl Toxicol 2012;32:934-43. doi: 10.1002/ jat.2781

43. Collins AR, Duthie SJ, Dobson VL. Direct enzymic detection of endogenous oxidative base damage in human lymphocyte DNA. Carcinogenesis 1993;14:1733-5. doi: 10.1093/ carcin/14.9.1733

44. Smith CC, O'Donovan MR, Martin EA. hOGG1 recognizes oxidative damage using the comet assay with greater specificity than FPG or ENDOIII. Mutagenesis 2006;21:18590. doi: 10.1093/mutage/gel019

45. Jalili P, Huet S, Lanceleur R, Jarry G, Le Hegarat L, Nesslany F, Hogeveen K, Fessard V. Genotoxicity of aluminum and aluminum oxide nanomaterials in rats following oral exposure. Nanomaterials (Basel) 2020;10:305-17. doi: 10.3390/nano 10020305

46. Akbaba GB, Türkez H. Investigation of the genotoxicity of aluminum oxide, $\beta$-tricalcium phosphate, and zinc oxide nanoparticles in vitro. Int J Toxicol 2018;37:216-22. doi: $10.1177 / 1091581818775709$

47. Guichard Y, Schmit J, Darne C, Gaté L, Goutet M, Rousset D, Rastoix O, Wrobel R, Witschger O, Martin A, Fierro V, Binet S. Cytotoxicity and genotoxicity of nanosized and microsized titanium dioxide and iron oxide particles in Syrian hamster embryo cells. Ann Occup Hyg 2012;56:631-64. doi: 10.1093/annhyg/mes006

48. Adamcakova-Dodd A, Stebounova LV, O'Shaughnessy PT, Kim JS, Grassian VH, Thorne PS. Murine pulmonary responses after sub-chronic exposure to aluminum oxidebased nanowhiskers. Part Fibre Toxicol 2012;9:22. doi: 10.1186/1743-8977-9-22

49. Liu Y, Xia Q, Liu Y, Zhang S, Cheng F, Zhong Z, Wang L, $\mathrm{Li} \mathrm{H}$, Xiao K. Genotoxicity assessment of magnetic iron oxide nanoparticles with different particle sizes and surface coatings. Nanotechnology 2014;25:425101. doi: $10.1088 / 0957-4484 / 25 / 42 / 425101$ 
50. Singh SP, Rahman MF, Murty US, Mahboob M, Grover P. Comparative study of genotoxicity and tissue distribution of nano and micron sized iron oxide in rats after acute oral treatment. Toxicol App Pharmacol 2013;266:56-66. doi: 10.1016/j.taap.2012.10.016

51. Lee IC, Ko JW, Park SH, Shin NR, Shin IS, Moon C, Kim $\mathrm{JH}, \mathrm{Kim} \mathrm{HC}, \mathrm{Kim}$ JC. Comparative toxicity and biodistribution assessments in rats following subchronic oral exposure to copper nanoparticles and microparticles. Part Fibre Toxicol 2016;13:56-71. doi: 10.1186/s12989-016-0169-x

52. De Jong WH, De Rijk E, Bonetto A, Wohlleben W, Stone V, Brunelli A, Badetti E, Marcomini A, Gosens I, Cassee FR. Toxicity of copper oxide and basic copper carbonate nanoparticles after short-term oral exposure in rats Nanotoxicology $2019 ; 13: 50-72$. doi : $10.1080 / 17435390.2018 .1530390$

53. Cholewińska E, Ognik K, Fotschki B, Zduńczyk Z, Juśkiewicz J. Comparison of the effect of dietary copper nanoparticles and one copper (II) salt on the copper biodistribution and gastrointestinal and hepatic morphology and function in a rat model. PloS One 2018;13:e197083. doi: 10.1371/journal.pone.0197083

54. Chen Z1, Meng H, Xing G, Chen C, Zhao Y, Jia G, Wang T, Yuan H, Ye C, Zhao F, Chai Z, Zhu C, Fang X, Ma B, Wan L. Acute toxicological effects of copper nanoparticles in vivo. Toxicol Lett 2006;25:109-20. doi: 10.1016/j. toxlet.2005.10.003

55. Chakraborty R, Basu T. Metallic copper nanoparticles induce apoptosis in a human skin melanoma A-375 cell line. Nanotechnology 2017;28:105101. doi: 10.1088/1361-6528/ aa57b

56. Schins RP, Knaapen AM. Genotoxicity of poorly soluble particles. Inhal Toxicol 2007;19(Suppl 1): 189-98. doi: 10.1080/08958370701496202

57. Tucker JD, Preston RJ. Chromosome aberrations, micronuclei, aneuploidy, sister chromatid exchanges, and cancer risk assessment. Mutat Res 1996;365:147-59. doi: 10.1016/ s0165-1110(96)90018-4

58. Yu Q, Xiong X, Zhao L, Xu TT, Bi H, Fu R, Wang QH Biodistribution and toxicity assessment of superparamagnetic iron oxide nanoparticles in vitro and in vivo. Curr Med Sci 2018;38:1096-102. doi: 10.1007/s11596-018-1989-8

59. Canli E, Canli M. Effects of aluminum, copper, and titanium nanoparticles on some blood parameters in Wistar rats. Turk J Zool 2017;41:259-66. doi: 10.3906/zoo-1512-23
60. M'rad I, Jeljeli M, Rihane N, Hilber P, Sakly M, Amara S. Aluminium oxide nanoparticles compromise spatial learning and memory performance in rats. EXCLI J 2018;17:200-10. doi: 10.17179/excli2017-1050

61. Zhang Q, Ding Y, He K, Li H, Gao F, Moehling TJ, Wu X, Duncan J, Niu Q. Exposure to alumina nanoparticles in female mice during pregnancy induces neurodevelopmental toxicity in the offspring. Front Pharmacol 2018;9:253. doi: 10.3389/fphar.2018.00253

62. Prabhu BM, Ali SF, Murdock RC, Hussain SM, Srivatsan M. Copper nanoparticles exert size and concentration dependent toxicity on somatosensory neurons of rat. Nanotoxicology $2010 ; 4: 150-60$. doi : 10.3109/17435390903337693

63. Yousef MI, Abuzreda AA, Kamel, MA. Cardiotoxicity and lung toxicity in male rats induced by long term exposure to iron oxide and silver nanoparticles. Exp Ther Med 2019;18:4329-39. doi: 10.3892/etm.2019.8108

64. Yousef MI, Mutar TF, Kamel MA. Hepato-renal toxicity of oral sub-chronic exposure to aluminum oxide and/or zinc oxide nanoparticles in rats. Toxicol Rep 2019;6:336-46. doi: 10.1016/j.toxrep.2019.04.003

65. Lee IC, Ko JW, Park SH, Lim JO, Shin IS, Moon C, Kim $\mathrm{SH}, \mathrm{Heo}$ JD, Kim JC. Comparative toxicity and biodistribution of copper nanoparticles and cupric ions in rats. Int $\mathrm{J}$ Nanomedicine 2016;11:2883-900. doi: 10.2147/IJN. S106346

66. Lai X, Zhao H, Zhang Y, Guo K, Xu Y, Chen S, Zhang J. Intranasal delivery of copper oxide nanoparticles induces pulmonary toxicity and fibrosis in C57BL/6 mice. Sci Rep 2018;8:4499. doi: 10.1038/s41598-018-22556-7

67. Li H, Huang T, Wang Y, Pan B, Zhang L, Zhang Q, Niu Q. Toxicity of alumina nanoparticles to immune system in mice. Nanomedicine (Lond) 2020;15:927-46. doi: 10.2217/nnm2020-0009

68. Xu Y, Sherwood JA, Lackey KH, Qin Y, Bao Y. The responses of immune cells to iron oxide nanoparticles. J Appl Toxicol 2016;36:543-53. doi: 10.1002/jat.3282

69. Triboulet $\mathrm{S}$, Aude-Garcia C, Carrière M, Diemer H, Proamer F, Habert A, Chevallet M, Collin-Faure V, Strub JM, Hanau D, Van Dorsselaer A, Herlin-Boime N, Rabilloud T. Molecular responses of mouse macrophages to copper and copper oxide nanoparticles inferred from proteomic analyses. Mol Cell Proteomics 2013;12:3108-22. doi: 10.1074/mcp. M113.030742

\section{Genotoksičnost nanočestica aluminijeva oksida, željeznog oksida i bakra u mišjim stanicama koštane srži}

Cilj ovog istraživanja bio je ocijeniti genotoksično djelovanje nanočestica $\mathrm{Al}_{2} \mathrm{O}_{3}, \mathrm{Fe}_{2} \mathrm{O}_{3}$ i Cu pomoću citogenetičkih testova kromosomskih aberacija, mikronukleus- i komet-testa u stanicama koštane srži muških BALB/c miševa. Miševi su intraperitonalnom injekcijom 14 dana primali jednu od triju doza $\mathrm{Al}_{2} \mathrm{O}_{3}$ ili $\mathrm{Fe}_{2} \mathrm{O}_{3}(75,150$ ili $300 \mathrm{mg} / \mathrm{kg})$ odnosno $\mathrm{Cu}(5$, 10 ili $15 \mathrm{mg} / \mathrm{kg}$ ) nanočestica jednom na dan, dok je negativna kontrolna skupina primala destiliranu vodu a pozitivna mitomicin $\mathrm{C}$ i metil-metansulfonat. Nanočestice $\mathrm{Al}_{2} \mathrm{O}_{3} \mathrm{i} \mathrm{Fe}_{2} \mathrm{O}_{3}$ nisu iskazale genotoksično djelovanje, ali je zato bakar potaknuo značajnu $(\mathrm{P}<0,05)$ genotoksičnost u odnosu na negativnu kontrolu. Naši rezultati nadopunjuju spoznaje o rizicima za zdravlje povezanima s profesionalnom i drugom izloženosti (npr. putem potrošačke robe ili gdje se takve čestice primjenjuju u svrhu liječenja) nanočesticama $\mathrm{Al}_{2} \mathrm{O}_{3}, \mathrm{Fe}_{2} \mathrm{O}_{3} \mathrm{i} \mathrm{Cu}$ u ljudi te mogu poslužiti kao referenca pri utvrđivanju neškodljivih razina izloženosti u regulacijskim aktima. Potrebna su, međutim, daljnja istraživanja kronične toksičnosti ovih nanočestica in vivo kako bi se osigurala njihova sigurna primjena i spriječila štetna prisutnost u okolišu.

KLJUČNE RIJEČI: $\mathrm{Al}_{2} \mathrm{O}_{3} ; \mathrm{Cu} ; \mathrm{Fe}_{2} \mathrm{O}_{3}$; in vivo; kromosomske aberacije; komet-test; mikronukleus; mitotski indeks 